\title{
ANALISIS TENTANG PENGARUH MOTIVASI DAN MINAT TERHADAP SIKAP UNTUK BERWIRAUSAHA MAHASISWA PROGRAM STUDI PENDIDIKAN EKONOMI IKIP PGRI MADIUN
}

\author{
M.Th.Kuswariningsih \\ Dosen Prodi Pendidikan Ekonomi IKIP PGRI Madiun
}

Abstract

An individual has a driving factor either consciously or unconsciously, it is motivation. Once a person experiences a state that encourages behavior toward a goal, then the resulting realization that an object, or something about the situation contained nothing to do with him. Thus the individual has an interest which is welcome consciously, because if not so then interest has no meaning at all. With the motivation of the individual self and the interest in entrepreneurship began to determine the attitude of an individual that is a typical way of behaving that is focused on specific issues, which in this case is selfemployed

This study aims to determine motivation, interest, attitude of students of entrepreneurship on Economics Education Program at IKIP PGRI Madiun and the influence of motivation and interest in the attitude of students of entrepreneurship on Economic Education Teachers' Training College PGRI Madiun. The population in this study were 100 students with a sample of 30 students with a sampling technique that is purposive sampling. Techniques of data collection obtained by using questionnaires and documentation. Hypothesis was tested using multiple linear regression, the $\mathrm{F}$ test and $\mathrm{t}$ test.

The results of this study are ) students who have very good motivation as much as 1 or $3.33 \%$, (b ) students who have a good motivation as many as 8 people, or $26.67 \%$, (c ) students who have a good enough motivation as many as 13 people or 43.33 (d ) students who are less well motivated as much 7 orang or $23.33 \%$, and ( e ) students who have a very poor motivation as much as 1 or $3.33 \%$, while students who have an interest in very good as much as 1 or $3.33 \%$, (b ) a student who has an interest either as many as 12 people or $40.00 \%$, (c ) students who have an interest in good enough as many as 11 people or 36.67 (d ) students who have unfavorable interest as much as 3 or $10.00 \%$, and (e ) students who have an interest in very poor as many as 3 people or $10.00 \%$ of the test proved that the correlation value is 0.973 while the value rhit rtab with a significance level of $5 \%$ with $\mathrm{N}$ 30 at 0,361 . This means that rhit $\geq \operatorname{rtabel}(0.973 \geq 0.361)$. This situation can be said that the $\mathrm{HO}$ is rejected and $\mathrm{Ha}$ accepted means there is a relationship of motivation and interest in entrepreneurship attitude. On the other hand, if viewed from the determination or donation motivation and interest in entrepreneurship attitude is that the magnitude of the value of $\mathrm{R} 2$. or $\mathrm{R}$ sequare of 0.947 which means donations motivation and interest in entrepreneurship attitude was $97.70 \%$, while the remaining $2.30 \%$ is influenced by other factors Of the F test, proved that the F value $\geq$ Ftable ( $240.667 \geq 5.49$ ) or $\leq$ Sighit Sigprob $(0.000 \leq 0.05)$. Fhit value at $5 \%$ significance level with df 2 and 27 residues of 5.49 . overall means of motivation and interest in entrepreneurship affect the entrepreneurial attitude.

From the equation $\mathrm{Y}=2,514+0.745 \mathrm{X} 1-0.086 \mathrm{X} 2$. If motivation is increased by $1 \%$, and an increase in entrepreneurship attitude of $0.745 \%$, when other factors are considered constant. If the interest is increased by $1 \%$, will decrease by $0.086 \%$ entrepreneurial attitude when other factors are considered constant. In the test derived from motivational variables thit value is 20.670 while the value ttabel at significance level of $5 \%$ and at $\mathrm{DK}=\mathrm{NK}=27$ at 2,052 , this means thitu $\geq \operatorname{ttab}(\geq 20.6702 .052)$ means that there are different motivational variables influence the entrepreneurial attitude. Of the $t$ test, the variable interest thit value obtained is -2.050 while the value ttabel at significance level of $5 \%$ and $\mathrm{DK}=\mathrm{NK}=27$ at 2,052, this means thitu ttab ( -2.0502 .052 ) difference means no influence interest in entrepreneurship attitude . This study therefore concluded that there are significant between motivation and interest in student attitudes to entrepreneurship on Economics Education Program at IKIP PGRI Madiun. 
Keyword: motivation, interest, and entrepreneurship

Pendahuluan

Salah satu ciri esensial dari individu ialah bahwa ia selalu melakukan kegiatan atau berperilaku. Kegiatan individu merupakan manifestasi dari hidupnya, baik sebagai individu maupun sebagai mahluk sosial. Individu melakukan kegiatan selalu dalam interaksi dengan lingkungannya, lingkungan manusia dan bukan manusia.

Penyesuaian diri merupakan salah satu bentuk interaksi yang didasari oleh adanya penerimaan atau saling mendekatkan diri terhadap hal-hal yang disenangi atau dirasakan menguntungkan. Individu akan melakukan berbagai bentuk penyesuaian. Dalam penyesuaian diri ini, yang diubah atau disesuaikan bisa hal-hal yang ada pada diri individu atau dapat juga hal-hal yang ada pada lingkungan yang diubah sesuai dengan kebutuhan individu atau secara serempak diantara keduanya.Bentuk penyesuaian yang ada pada diri individu yaitu dengan belajar.

Perilaku individu tidak berdiri sendiri, selalu ada hal-hal yang mendorongnya dan tertuju pada suatu tujuan yang ingin dicapainya. Tujuan dan faktor pendorong ini mungkin disadari oleh individu, mungkin juga tidak disadari. Para ahli seringkali menjelaskan perilaku individu dengan tiga pertanyaan yaitu Apa (What), Bagaimana (How) dan Mengapa (Why). Apa yang ingin dicapai atau tujuan individu mungkin sama, tetapi bagaimana mencapai dan mengapa individu ingin mencapainya mungkin berbeda. Demikian pula hal-hal yang mendorong perbuatan individu mungkin sama tetapi tujuan dan cara individu untuk mencapainya bisa berbeda.

Kita sering melihat motivasi siswa tercermin dalam motivasi pribadi dan dalam keterlibatan kognitif, emosional dan perilaku diberbagai aktivitas sekolah.Jeane Ellis Ormrod,(2002:58) berpendapat bahwa semua siswa termotivasi dalam suatu cara tertentu. Seorang siswa mungkin tertarik pada mata pelajaran di kelas dan mencari tugas yang menantang, berpartisipasi secara aktif dalam diskusi kelas, serta mendapatkan nilai tinggi dalam proyek-proyek yang ditugaskan. Siswa lain mungkin lebih tertarik dengan sisi sosial sekolah, sering berinteraksi dengan teman sekelas, hampir setiap hari mengikuti aktivitas ekstrakurikuler dan mungkin mencalonkan diri sebagai ketua kelas. Siswa lain mungkin berfokus pada atletik, unggul dikelas pelajaran fisik, hampir setiap siang dan akhir pekan bermain atau melihat pertandingan olah raga, dan mengikuti perkumpulan fitness.

Setelah seseorang mengalami keadaan yang mendorong berperilaku kearah tujuan (motivasi), maka timbul kesadaran bahwa suatu obyek, sesuatu soal atau situasi mengandung sangkut paut dengan dirinya. Dengan demikian individu tersebut mempunyai minat yang merupakan sambutan secara sadar, sebab kalau tidak demikian maka minat tidak mempunyai arti sama sekali. Pengetahuan atau informasi tentang kewirausahaan harus lebih dahulu diperoleh sebelum minat untuk berwirausaha itu timbul. Minat untuk berwirausaha merupakan hasil pendidikan yang pernah diperolehnya. Orang yang benar-benar terdidik ditandai adanya minat yang benar-benar luas serta benar-benar dalam terhadap hal-hal yang bernilai.

Seseorang yang mempunyai minat terhadap berwirausaha berarti bahwa dalam mengejar tugasnya dia mengalami efek positif yang signifikan seperti kesenangan, kegembiraan. Harapannya adalah akan menghasilkan keuntungan dan dapat menimbulkan kepuasan bagi dirinya. Apabila kesenangan merupakan minat sementara maka kepuasan merupakan minat yang sifatnya tetap.

Dengan motivasi yang ada pada diri individu dan minat terhadap kewirausahaan maka seorang individu mulai menentukan sikap yaitu cara bertingkah laku yang khas yang tertuju pada persoalan-persoalan tertentu, yang ada dalam hal ini ini adalah berwirausaha. Sikap merupakan kesiapan atau keadaan siap untuk 
timbulnya suatu perbuatan atau tingkah laku. Sebagai reaksi sikap selalu berhubungan dengan dua hal yaitu senang atau tidak senang, suka atau tidak suka.

Menurut Abin Syamsuddin,(2007:37,) bahwa motivasi merupakan suatu kekuatan ( power) atau tenaga ( forces ) atau daya ( energy) atau suatu keadaan yang kompleks ( a complex state) dan kesiap sediaan (preparatory set ) dalam diri individu ( organisme) untuk bergerak ( to move, motion, motive) kearah tujuan tertentu, baik disadari maupun tidak disadari. Motivasi tersebut tibul dan tumbuh berkembang dengan jalan 1) datang dari dalam diri individu itu sendiri ( intrinsik ) dan 2) datang dari lingkungan ( ekstrinsik )

a. Berdasarkan penggolongannya,motivasi dibedakan:

1) Motif primer ( primary motive) atau motif dasar ( basic motive) menunjukkan kepada motif yang tidak dipelajari ( unlearned motive) yang untuk ini sering juga digunakan istilah dorongan (drive ). Golongan motif ini dibedaka atas :

a) Dorongan fisiologis yang bersumber pada kebutuhan organis yang mencakup antara lain lapar, haus, pernapasan, seks kegiatan dan istirahat. Untuk menjamin kelangsungan hidup organisaan diperlukan pemenuhan kebutuhan-kebutuhan tersebut sehingga dicapai keadaan fisik yang seimbang.

b) Dorongan umum dan motif darurat, termasuk didalamnya dorongan takut, kasih sayang, kegiatan, kekaguman dan ingin tahu dalam hubungannya dengan rangsangan dari luar termasuk dorongan untuk melarikan diri, menyerang, berusaha dan mengejar dalam rangka menyelamatkan dirinya. Motif-motif yang termasuk kedalam kategori primer tersebut pada umumnya terjadi secara natural dan instinktif.

2) Motif Sekunder ( secondary motives) menunjukkan pada motif yang berkembang dalam diri individu karena pengalaman. Dan dipelajari. Kedalam golongan ini termasuk antara lain

a) Takut yang dipelajari.

b) Motif-motif sosial ( ingin diterima, dihargai, konformitas, afiliasi, persetujuan, status, merasa aman dan sebagainya )

c) Motif-motif obyektif dan interes ( eksplorasi, manipulasi, minat )

d) Maksud dan aspirasi.

e) Motif berprestasi

Manusia sebagai organisme mengalami proses perkembangan. Perkembangan ini berhubungan dengan upaya memenuhi kebutuhan hidupnya. Menurut Abraham Maslow (dalam Nana Syaodih Sukmadinata,2011:68) kebutuhan hidup manusia meliputi:

a. Physiological needs (kebutuhan fisik, sandang, pangan dan papan)

b. Safety need (kebutuhan akan rasa aman)

c. Belongingness needs (kebutuhan untuk dihargai)

d. Self actualization (kebutuhan akan aktualisasi diri)

Adanya dorongan dalam diri manusia untuk berbuat, memenuhi kebutuhan akan hidupnya disebut dengan motif. Dapat dikatakan motif sebagai kekuatan yang ada dalam diri manusia yang menyebabkannya bertindak atau berbuat untuk memenuhi kebutuhannya ataupun mencapai tujuan tertentu. Motif lebih menekankan pada dorongan internal dalam diri individu seperti halnya :

a. Organic motive (makan, minum, seks dan istirahat)

b. Emergency motives (melepaskan diri dari bahaya, melawan/ mengatasi rintangan).

c. Obyective motives (menjalin relasi sosial dengan sesama lingkungannya).

Motivasi merupakan keadaan dalam diri individu atau organisme yang mendorong perilaku kearah tujuan. Dengan demikian dapat dikemukakan 
motivasi mempunyai tiga aspek yaitu 1) keadaan terdorong dari diri organisme, yaitu kesiapan bergerak karena kebutuhan misalnya kebutuhan jasmani, karena keadaan lingkungan, atau karena keadaan mental seperti berpikir dan ingatan, 2) perilaku yang timbul dan terarah karena keadaan ini, dan 3) sasaran atau tujuan yang dituju oleh perilaku tersebut.

Whitherington (dalam Buchori,1991:135) berpendapat bahwa minat adalah kesadaran seseorang, bahwa suatu obyek , seseorang, suatu soal atau situasi mengandung sangkut paut dengan dirinya. Rupa-rupanya minat harus dipandang sebagai suatu sambutan yang sadar; kalau tidak demikian minat itu tidak mempunyai arti sama sekali. Oleh sebab itu pengetahuan atau informasi tentang seseorang atau suatu obyek pasti harus ada lebih dulu daripada minat terhadap orang atau obyek tadi.

Menurut Witherington dalam Buchori (1991:63), minat adalah dorongan yang menyebabkan terikatnya perhatian individu pada obyek tertentu seperti pekerjaan, pelajaran, benda dan orang. Minat berhubungan dengan aspek kognitif, afektif dan motorik dan merupakan sumber motivasi untuk melakukan apa yang diinginkan. Minat berhubungan dengan sesuatu yang menguntungkan dan dapat menimbulkan kepuasan bagi dirinya. Kesenangan merupakan minat yang sifatnya sementara. Adapun minat bersifat tetap (persistent) dan ada unsur memenuhi kebutuhan dan memberikan kepuasan. Semakin sering minat diekspresikan dalam kegiatan akan semakin kuat minat tersebut, sebaliknya minat akan menjadi pupus kalau tidak ada kesempatan untuk mengekspresinya.

Minat memiliki sifat dan karakter khusus, sebagai berikut:

1) Minat bersifat pribadi (individual), ada perbedaan antara minat seseorang dan orang lain.

2) Minat menimbulkan efek diskriminatif.

3) Erat hubungannya dengan motivasi, mempengaruhi, dan dipengaruhi motivasi.

4) Minat merupakan sesuatu yang dipelajari, bukan bawaan lahir dan dapat berubah tergantung pada kebutuhan, pengalaman dan mode.

Sebetulnya masalah minat tidak lepas hubungannya dengan masalah motivasi. Motivasi muncul karena ada kebutuhan, demikan pula dengan minat sehingga dapat dikatakan apabila minat merupakan alat motivasi yang pokok. Agar minat dapat dibangkitkan maka perlu usaha, menurut Sardiman AM (1992, dalam Slameto,2010:37) yaitu dengan cara membangkitkan adanya suatu kebutuhan, menghubungkan dengan persoalan pengalaman yang lampau, memberi kesempatan untuk mendapatkan hasil yang baik dan menggunakan berbagai macam bentuk belajar. Sedangkan menurut Slameto (2010:38) cara yang efektif untuk membangkitkan minat pada suatu obyek yang baru adalah dengan menggunakan minat-minat siswa yang telah ada. Misalnya siswa menaruh minat pada olah raga balap mobil maka sebelumnya mengajarkan kecepatan gerak, pengajar dapat menarik perhatian siswa dengan menceritakan sedikit mengenai balap mobil yang baru saja berlangsung.Disamping memanfaatkan minat yang ada (Tanner\&Tanner dalam Slameto,2010:39) menyarankan agar para pengajar juga berusaha membentuk minat-minat baru pada diri siswa. Disamping memanfaatkan minat yang ada (Tanner\&Tanner dalam Slameto,2010:39) menyarankan agar para pengajar juga berusaha membentuk minat-minat baru pada diri siswa.

Whitherington (dalam Buchori,1991:137) berpendapat bahwa sikap adalah kecenderungan untuk berpikir atau merasa dalam cara yang tertentu 
atau menurut saluran-saluran tertentu. Sikap adalah cara bertingkah laku yang khas, yang tertuju terhadap orang-orang, rombongan-rombongan atau persoalan-persoalan. Sedangkan cita-cita adalah suatu standard mengenai nilai-nilai. Cita-cita merupakan ukuran atau kriterium yang digunakan untuk mengukur tingkah laku atau kelakuan. Untuk sebagian cita -cita seseorang menentukan sikap orang itu.

Ada beberapa faktor yang mempengaruhi perkembangan sikap yaitu pertama, prestise. Apabila seseorang yang berprestise besar memperlihatkan suatu sikap atau menentukan posisi terhadap suatu persoalan, maka sikapnya ini biasanya akan dioper atau ditiru oleh orang lain, atau setidak-tidaknya akan mengubah atau mempengaruhi sikap orang-orang lain.Kedua adalah otoritet atau para ahli. Faktor lain timbul dari pengalaman yang menyakitkan hati.

Menurut Yudrik Yahya (2011:67) , sikap merupakan kesiapan atau keadaan siap untuk timbulnya suatu perbuatan atau tingkah laku. Sikap juga merupakan organisasi keyakinan-keyakinan seseorang mengenai obyek atau situasi yang relatif ajek, yang memberi dasar kepada orang untuk membuat respons dalam cara tertentu. Sikap merupakan penentu dalam tingkah laku manusia, sebagai reaksi sikap selalu berhubungan dengan dua hal yaitu "like" dan "dislike" (senang atau tidak senang, suka atau tidak suka). Mengacu pada adanya faktor perbedaan individu (pengalaman, latar belakang, pendidikan, dan kecerdasan), maka reaksi yang dimunculkan terhadap satu obyek tertentu akan berbeda pada setiap orang. Sikap mempunyai tiga komponen dasar, yaitu : 1) komponen kognisi, yang berhubungan dengan beliefs, ide, dan konsep.2) komponen afeksi, yang berhubungan dengan dimensi emosional seseorang. 3) komponen konasi psikomotorik, yang berhubungan dengan kecenderungan atau untuk bertingkah laku.

Pengertian wirausaha sama dengan pengertian wiraswasta. Wiraswasta terdiri atas tiga kata yaitu wira, swa dan sta, masing-masing berarti wira adalah manusia unggul, teladan, berbudi luhur, berjiwa besar, berani, pahlawan/pendekar kemajuan dan memiliki keagungan watak. Swa artinya sendiri dan sta artinya berdiri.

Bertolak dari ungkapan etimologis tersebut, maka wiraswasta berarti keberanian, keutamaan serta keperkasaan dalam memenuhi kebutuhan serta memecahkan permasalahan hidup dengan kekuatan yang ada pada diri sendiri. (Wasti Sumanto,1984:43 dalam Buchari Alma,2005:15). Menurut Haryati Subadio, pengertian wiraswata adalah manusia teladan yang berbudi luhur yaitu manusia yang mampu berdiri atas kemampuan sendiri, tidak saja dalam sektor swasta tapi juga dalam sektor negara. (Buchari Alma,2005:17), Sedangkan menurut Sudjoko bahwa wiraswasta adalah mereka ang memiliki nilai-nilai manusia perintis, pelopor dan pejuang kemerdekaan, pejuang kemajuan.Nilai-nilai ini adalah watak, kepribadian wiraswasta, jiwa semangat dan ketrampilan wiraswasta.(Buchari Alma:18). Selanjutnya Soesarsono Wijandi (1988:24 dalam Buchari Alma,2005:18) wiraswasta bukanlah teladan dalam usaha partikelir (swasta), melainkan adalah sifat-sifat keberanian, keutamaan, keteladanan dan semangat yang bersumber dari kekuatan sendiri, dari seorang pendekar kemajuan baik dalam kekaryaan pemerintahan maupun dalam kegiatan apa saja diluar pemerintahan dalam arti yang menjadi pangkal keberhasilan seseorang.

Dari beberapa pengertian tersebut, wirausaha atau wiraswasta adalah seorang yang memiliki keberanian, mampu melihat kedepan, mampu memecahkan masalah, memiliki semangat yang bersumber dari kemampuan sendiri. 
Sifat-sifat yang perlu dimiliki wirausaha:

1) Percaya diri. Percaya diri dimulai dari pribadi yang mantab, tidak mudah terombang ambing oleh pendapat atau saran orang lain. Namun saran orang lain tidak ditolak mentah-mentah, dipakai sebagai masukan untuk dipertimbangkan. Orang yang percaya diri adalah orang yang sudah mapan jasmani dan rohaninya. Pribadinya merupakan pribadi yang independen dan sudah mencapai tingkat maturity (kematangan).

2) Berorientasi pada tugas dan hasil. Orang semacam ini tidak mengutamakan prestise terlebih dahulu melainkan gandrung pada prestasi baru. Setelah berhasil maka prestisenya akan naik

3) Berani mengambil resiko. Resiko yang dihadapi seperti persaingan, harga turun naik, barang tidak laku merupakan tantangan yang harus dihadapi dengan penuh perhitungan.

4) Memiliki jiwa kepemimpinan. Sifat kepemimpinan kini dapat dipelajari dan dilatih namun sifat kepemimpinan ada dalam diri masing-masing individu. Ada pemimpin yang disenangi bawahan, ada pemimpin yang tidak disenangi bawahan. Pemim[in yang baik harus mau menerima kritik dari bawahan, ia harus bersifat responsif.

5) Keorisinilan. Sifat orisinil tidak selalu ada pada diri seseorang. Yang dimaksud orisinil ialah tidak mengekor atau meniru orang lain tetapi memiliki ciri khas sendiri, ada ide yang orisinil

6) Berorientasi pada masa depan. Seorang wirausaha haruslah perspektif, mempunyai visi kedepan, apa yang hendak ia lakukan. apa yang ingin dicapai, sebab suatu usaha bukan didirikan untuk sementara tetapi untuk selamanya.Oleh sebab itu faktor kontinuitas harus dijaga dan pandangan harus ditujukan jauh kedepan. Untuk menghadapi pandangan jauh kedepan. Seorang wirausaha akan menyusun perencanaan dan strategi yang matang agar jelas langkah-langkah yang akan dilaksanakan.

7) Kreativitas. Sifat keorisinilan seorang wirausaha menuntut adanya kreativitas dalam pelaksanaan tugasnya. Kreativitas aalah kemampuan untuk membuat kombinasi-kombinasi baru atau melihat hubunganhubungan baru antara unsur, data, variabel yang sudah ada sebelumnya. (Buchari Alma,2005:51)

Minat untuk berwirausaha merupakan hasil yang berhubungan dengan sesuatu yang menguntungkan dan dapat menimbulkan kepuasan bagi dirinya.Kesenangan merupakan minat yang sifatnya sementara. Adapun minat yang bersifat tetap (persistent) dan ada unsur memenuhi kebutuhan dan memberikan kepuasan.(Yudrik Yahya,2011:63)

Seseorang yang mempunyai minat terhadap berwirausaha berarti bahwa dalam mengejar tugasnya dia mengalami efek positif yang signifikan seperti kesenangan, kegembiraan. Harapannya adalah akan menghasilkan keuntungan dan dapat menimbulkan kepuasan bagi dirinya. Apabila kesenangan merupakan minat sementara maka kepuasan merupakan minat yang sifatnya tetap.

Dengan motivasi yang ada pada diri individu dan minat terhadap kewirausahaan maka seorang individu mulai menentukan sikap yaitu cara bertingkah laku yang khas yang tertuju pada persoalan-persoalan tertentu, yang adalam hal ini ini adalah bereirausaha. Menurut Yudrik Yahya (2011:67) sikap merupakan kesiapan atau keadaan siap untuk timbulnya suatu perbuatan atau tingkah laku. Sebagai reaksi sikap selalu berhubungan dengan dua hal yaitu senang atau tidak senang, suka atau tidak suka. 


\section{Metodologi Penelitian}

Penelitian ini dilakukan di IKIP PGRI MADIUN khususnya di Program Studi Pendidikan Ekonomi yang beralamat Jl. Setiabudi 85 Madiun.

Pemilihan lokasi penelitian ini didasarkan pada pertimbangan adanya permasalahan-permasalahan yang relevan dengan penelitian yang akan dilakukan, yaitu :

1) Berwirausaha merupakan alternatif bagi mahasiswa kelak setelah lulus Strata Satu (S1) disamping pekerjaan sebagai tenaga pendidik (guru).

2) Pemberian motivasi perlu supaya mahasiswa mempunyai keinginan atau minat dan selanjutnya menentukan sikap untuk berwirausaha;

3) Selama ini belum pernah ada yang meneliti masalah motivasi, minat dan sikap untuk berwirausaha dilingkup IKIP PGRI MADIUN.

Metode yang digunakan dalam penelitian ini adalah dengan menggunakan statistik deskriptif, yaitu untuk memberi gambaran tentang distribusi data. Statistik deskriptif meliputi rata-rata, minimum, maksimum serta standar deviasi yang bertujuan mengetahui distribusi data yang menjadi sampel penelitian.

Penelitian ini mempunyai 2 variabel bebas yaitu X1 sebagai motivasi untuk berwirausaha, $\mathrm{X} 2$ sebagai minat untuk berwirausaha dan $\mathrm{Y}$ merupakan variabel terikat yaitu sikap untuk wirausaha.

Agar lebih jelasnya dapat dilihat pada gambar sebagai berikut :

motivasi

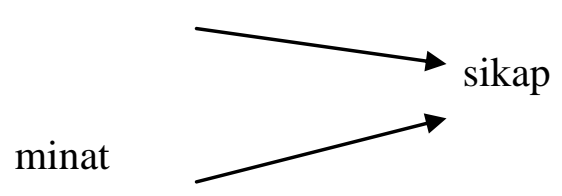

\section{Definisi Operasional}

\section{Variabel Bebas (independent)}

a. Motivasi

Menurut Abin Syamsuddin,(2007:37), bahwa motivasi merupakan suatu kekuatan ( power) atau tenaga (forces) atau daya (energy) atau suatu keadaan yang kompleks ( a complex state) dan kesiap sediaan (preparatory set) dalam diri individu ( organisme) untuk bergerak ( to move, motion, motive) kearah tujuan tertentu, baik disadari maupun tidak disadari.

b. Menurut Witherington dalam Buchori (1991:63), minat adalah dorongan yang menyebabkan terikatnya perhatian individu pada obyek tertentu seperti pekerjaan, pelajaran, benda dan orang.

\section{Variabel Terikat (dependent)}

Sikap

Whitherington (dalam Buchori,1991:137) berpendapat bahwa sikap adalah kecenderungan untuk berpikir atau merasa dalam cara yang tertentu atau menurut saluran-saluran tertentu. Sikap adalah cara bertingkah laku yang khas, yang tertuju terhadap orang-orang, rombongan-rombongan atau persoalanpersoalan.Jadi sikap untuk berwirausaha berarti cara bertingkah laku dengan suatu keberanian serta keperkasaan dalam memenuhi kebutuhan serta memecahkan permasalahan hidup dengan kekuatan yang ada pada diri sendiri. 


\section{Populasi, Sampel, Tehnik Pengambilan Sampel}

Populasi dalam penelitian ini adalah seluruh mahasiswa Program Studi Pendidikan Ekonomi di tahun Akademik 2013 - 2014 yang berjumlah 100 mahasiswa. Sampel dalam penelitian ini sebanyak 30 mahasiswa. Tehnik pengambilan sampel menggunakan purposive sampling yaitu mahasiswa yang sudah menempuh dan lulus mata kuliah Kewirausahaan

Data dalam penelitian ini dikumpulkan dengan menggunakan tehnik :

1. Tehnik Dokumentasi

Cara ini digunakan untuk melihat jumlah mahasiswa di masing-masing tingkat sehingga dapat diketahui jumlah seluruh mahasiswa.

2. Kuesioner

Pengumpulan data dengan tehnik kuesioner dilakukan dengan menyebarkan daftar pertanyaan kepada responden dengan harapan mereka akan memberikan respon terhadap daftar pertanyaan tersebut.

Dalam penelitian uji validitas dilakukan atas item-item pertanyaan pada kuesioner yaitu dengan jalan menghitung koefisien korelasi dari tiap-tiap item pertanyaan dengan menggunakan korelasi product moment. Dalam penelitian ini pengujian reliabilitas terhadap instrumen menggunakan uji Cronbach s Alpha. Bila nilai alpha lebih besar dari 0,6 menunjukkan bahwa data telah reliabel.(Ghozali:2005).

\section{Uji Asumsi Klasik}

a. Uji Normalitas Data

Menurut Ghozali (2005), uji normalitas data dilakukan dengan tujuan untuk mengetahui apakah sampel yang diambil telah memenuhi kriteria sebaran atau distribusi normal. Data dikatakan terdistribusi dengan normal apabila hasil pengujian menunjukkan nilai residual memiliki nilai $\mathrm{p}$ diatas $5 \%$.

b. Uji Multikolinearitas

Menurut Ghozali (2005), multikolonieritas adalah situasi adanya korelasi antara variabel independen.Model regresi yang baik adalah model yang bebas multikolinearitas.

c. Uji Heteroskedastisitas

Ghozali (2005) menyatakan bahwa uji heterokedastisitas dilakukan untuk menguji apakah dalam model regresi terjadi ketidak samaan varian dari residual suatu pengamatan kepengamatan yang lain. Model regresi Uji Hipotesis yang baik adalah yang homokedastisitas atau tidak heterokedastisitas.

Hipotesis dalam penelitian diuji dengan menggunakan regresi linear berganda. Berikut ini persamaan regresi yang digunakan dalam penelitian ini.

$\mathrm{Y}=\alpha+\beta_{1} \mathrm{X} 1+\beta_{2} \mathrm{X} 2+\mathrm{e}$

Keterangan notasi :

$\mathrm{Y}=$ sikap untuk berwirausaha

$\mathrm{X} 1=$ motivasi untuk berwirausaha

$\mathrm{X} 2=$ minat untuk berwirausaha

$\beta_{1}-\beta_{2}=$ koefisien regresi

$\mathrm{E} \quad=$ error

Uji hipotesis dalam penelitian ini menggunakan regresi linear berganda sehingga analisis statistik meliputi pengujian berupa koefisien determinasi, nilai F regresi dan nilai t regresi (Ghozali, 2005) a.Koefisien Determinasi (Adjusted $R^{2}$ ) 
Koefisien determinasi adalah nilai yang menunjukkan seberapa besar variabel independen dapat menjelaskan variasi variabel dependennya. Nilai koefisien determinasi dapat dilihat pada hasil pengujian regresi linear pada tabel model summary. Koefisien determinasi yang dilihat adalah nilai dari adjusted $R^{2}$ (Ghozali,2005).

b.Nilai $\mathrm{F}$

Nilai F regresi merupakan alat yang digunakan untuk menguji apakah variabel independen berpengaruh secara bersama-sama atau simultan terhadap variabel independen (Ghozali,2005). Nilai $\mathrm{F}$ dalam penelitian ini dihitung dengan tingkat signifikansi 5\%. Jika nilai $\mathrm{F}$ memiliki p-value dibawah 5\%, hal ini berarti terdapat pengaruh simultan variabel independen terhadap variabel (Ghozali,2005)

\section{HASIL PENELITIAN}

\section{Deskripsi Variabel Motivasi Berwirausaha}

Suatu perbuatan termasuk perbuatan untuk bekerja, ataupun pemilihan suatu program, ataupun ingin bersikap tentunya didorong oleh adanya motivasi ataupun beberapa motivasi atau motif. Timbulnya dorongan atau kebutuhan tersebut merupakan suatu tenaga yang berada didalam diri seseorang (motivasi instrinsik), tetapi dorongan ini dapat pula ditimbulkan dari orang lain (motivai ekstrinsik). Dengan dorongan tersebut mereka akan berbuat untuk mencapai tujuan yang di inginkan.

Berdasarkan rekapitulasi jawaban angket variabel motivasi berwirausaha setelah dianalisis dengan statistik diskriptif dengan SPSS for Windows $v 16.0$ diperoleh hasil bahwa:

variabel motivasi dengan jumlah data $(\mathrm{N})$ sebanyak 30 orang memiliki deskripsi data sebagai berikut: (a) Nilai total skor sebesar 378; (b) Nilai mean sebesar 24,60; (c) Nilai median sebesar 26,00; (d) Nilai modus sebesar 26; (e) Standar deviasi sebesar 3,838; (f) Nilai minimum sebesar 15; (g) Nilai maksimum sebesar 32 .

Berdasarkan rentang skor motivasi berwirausaha tersebut dapat diperoleh hasil sebagai berikut : (a) mahasiswa yang mempunyai motivasi sangat baik sebanyak 1 orang atau 3,33\%; (b) mahasiswa yang mempunyai motivasi baik sebanyak 8 orang atau 26,67\%;(c) mahasiswa yang mempunyai motivasi yang cukup baik sebanyak 13 orang atau 43,33; (d) mahasiswa yang mempunyai motivasi yang kurang baik sebanyak 7orang atau 23,33\%; dan (e) mahasiswa yang mempunyai motivasi sangat kurang baik sebanyak 1 orang atau $3,33 \%$.

\section{Deskripsi Variabel Minat Berwirausaha}

Ada sebagian orang mengatakan hasrat sama dengan minat, namun sebenarnya antara hasrat dan minat mempunyai pengertian yang berbeda. Minat merupakan suatu keinginan terhadap segala sesuatu, yang umumnya diikuti dengan partisipasi aktif dalam kegiatan, sedangkan hasrat adalah suatu keinginan yang kuat atau dorongan) dan biasanya hasrat tidak berdiri sendiri tetapi berhubungan dengan kebutuhan. Hal ini dapat dikatakan apabila mahasisw mempunyai hasrat untuk berwirausaha berarti mahasiswa tersebut mempunyai keinginan untuk berwirausaha.

Variabel minat dalam penelitian berdasarkan jawaban angket yang diberikan kepada 30 orang responden Setelah dianalisis dengan statistik diskriptif dengan SPSS for Windows v 16.0 diperoleh hasil bahwa : 
variabel minat berwirausaha dengan jumlah data $(\mathrm{N})$ sebanyak 30 orang memiliki deskripsi data sebagai berikut: (a) Nilai total skor sebesar 728; (b) Nilai mean sebesar 24,23; (c) Nilai median sebesar 25,00; (d) Nilai modus sebesar 26; (e) Standar deviasi sebesar 3,298; (f) Nilai minimum sebesar 15; dan (g) Nilai maksimum sebesar 32.

Berdasarkan rentang skor minat berwirausaha tersebut dapat diperoleh hasil sebagai berikut : (a) mahasiswa yang mempunyai minat sangat baik sebanyak 1 orang atau 3,33\%; (b) mahasiswa yang mempunyai minat baik sebanyak 12 orang atau 40,00\%;(c) mahasiswa yang mempunyai minat yang cukup baik sebanyak 11 orang atau 36,67; (d) mahasiswa yang mempunyai minat yang kurang baik sebanyak 3 orang atau $10,00 \%$; dan (e) mahasiswa yang mempunyai minat sangat kurang baik sebanyak 3 orang atau $10,00 \%$.

\section{Deskripsi Variabel Sikap Berwirausaha}

Sikap merupakan suatu cara bertingkah laku yang khas dan ditujukan pada persoalan tertentu. Sikap merupakan kesiapan dalam melakukan suatu perbuatan yang berhubungan dengan senang dan tidak senang. Variabel sikap berwirausaha dalam penelitian ini diperoleh dari kuisioner yang dimiliki oleh 30 orang responden setelah dianalisis dengan statistik diskriptif dengan SPSS for Windows v 16.00 diperoleh hasil yaitu bahwa variabel sikap berwirausaha mahasiswa dengan jumlah data $(\mathrm{N})$ sebanyak 30 orang memiliki deskripsi data sebagai berikut: (a) Nilai total sikap sebesar 563; (b) Nilai mean sebesar 18,77 (c) Nilai median sebesar 20,00; (d) Nilai modus sebesar 20; (e) Standar deviasi sebesar 3,025; (f) Nilai minimum sebesar 10; (g) Nilai maksimum sebesar 24.

\section{Uji Prasarat}

Uji prasarat digunakan untuk menguji instrumen yang digunakan dalam penelitian ini yaitu variabel motivasi, minat, dan juga sikap untuk berwirausaha.

Dalam penelitian ini uji prasarat dilakukan untuk (a) uji normalitas; (b) Uji homoginitas; (c) uji validitas dan (d) uji reliabilitas untuk setiap variabel sebagai berikut:

\section{Uji Normalitas}

\section{a. Variabel Motivasi}

Pengujian normalitas untuk total skor angket motivasi berwirausaha dilakukan dengan menggunakan program SPSS for windows 16.0.

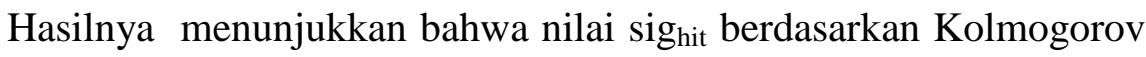
Smirnov sebesar 0,019 , apabila dikaji dengan sig $_{\text {pro }}$ sebesar 0,05 , dapat dikatakan bahwa $\operatorname{sig}_{\text {hit }}<\operatorname{sig}_{\text {pro }}(0,019<0,05)$ hal ini berarti $\mathrm{H}_{\mathrm{a}}$ diterima dan $\mathrm{H}_{\mathrm{o}}$ ditolak atau dapat dikatakan data tersebut ada bedanya atau tidak normal .

\section{b. Variabel Minat}

Pengujian normalitas untuk total skor angket minat berwirausaha dilakukan dengan menggunakan program SPSS for windows 16.0.

Berdasarkan Kolmogorov Smirnov sebesar 0,006, apabila dikaji dengan sig $_{\text {pro }}$ sebesar 0,05 , dapat dikatakan bahwa sig $\operatorname{sit}_{\text {hit }}<\operatorname{sig}_{\text {pro }}(0,006<0,05)$ hal ini berarti $\mathrm{H}_{\mathrm{a}}$ diterima dan $\mathrm{H}_{\mathrm{o}}$ ditolak atau dapat dikatakan data tersebut ada bedanya atau tidak normal.

c. Variabel Sikap Berwirausaha 
Pengujian normalitas untuk sikap berwirausaha dilakukan dengan menggunakan program SPSS for windows 16.0.

Berdasarkan Kolmogorov Smirnov sebesar 0,000, apabila dikaji dengan $\operatorname{sig}_{\text {pro }}$ sebesar 0,05 , dapat dikatakan bahwa $\operatorname{sig}_{\text {hit }}<\operatorname{sig}_{\text {pro }}(0,000<0,05)$ hal ini berarti $\mathrm{H}_{\mathrm{a}}$ diterima dan $\mathrm{H}_{\mathrm{o}}$ ditolak atau dapat dikatakan data tersebut ada bedanya atau tidak normal.

\section{Uji Homoginitas}

Atas uji homoginitas ke 3 variabel didasarkan pada jumlah skor dengan menggunakan program SPSS for windows 16.0, yang hasilnya adalah bahwa nilai sig ${ }_{\text {hit }}$ berdasarkan Test of Homogeneity of Variance pada Besed of mean sebesar 0,397 , apabila dikaji dengan sig pro sebesar 0,05 , dapat dikatakan bahwa sighit $>\operatorname{sig}_{\text {pro }}(0,397<0,05)$ hal ini berarti $\mathrm{H}_{\mathrm{a}}$ ditolak dan $\mathrm{H}_{\mathrm{o}}$ diterima atau dapat dikatakan data tersebut tidak ada bedanya atau homogin.

\section{Uji Validitas}

\section{a. Uji Validitas Motivasi}

Pengujian validitas untuk angket fungsi motivasi dilakukan atas dasar rekapitulasi jawaban responden untuk angket motivasi berwirausahadenganmenggunakan program SPSS for windows 16.0.

Hasilnys menunjukkan bahwa 8 item soal dalam angket tersebut secara keseluruhan dapat dikatakan valid karena nilai $r_{x y}>r_{\text {tabel }}$ pada taraf signifikansi 0,05 yaitu 0,361 . Oleh karena itu item soal dalam angket dapat digunakan untuk mengambil data dalam penelitian

b. Uji Validitas Minat

Pengujian validitas untuk angket minat berwirausaha dilakukan atas dasar rekapitulasi jawaban responden untuk angket minat dengan menggunakan program SPSS for windows 16.0.

Hasilnya menunjukkan bahwa 8 item soal dalam angket tersebut secara keseluruhan dapat dikatakan valid karena nilai $r_{x y}>r_{\text {tabel }}$ pada taraf signifikansi 0,05 yaitu 0,361 . Oleh karena itu item soal dalam angket dapat digunakan untuk mengambil data dalam penelitian.

c. Uji Validitas Sikap

Pengujian validitas untuk angket sikap berwirausaha dilakukan atas dasar rekapitulasi jawaban responden untuk angket sikap dengan menggunakan program SPSS for windows 16.0.

Hasilnya menunjukkan bahwa 6 item soal dalam angket tersebut secara keseluruhan dapat dikatakan valid karena nilai $r_{x y}>r_{\text {tabel }}$ pada taraf signifikansi 0,05 yaitu 0,361 . Oleh karena itu item soal dalam angket dapat digunakan untuk mengambil data dalam penelitian

\section{Uji Reliabilitas}

a. Uji Reliabilitas Motivasi

Pengujian reliabilitas untuk angket motivasi dilakukan atas dasar rekapitulasi jawaban responden untuk angket motivasi dengan menggunakan program SPSS for windows 16.0.

Hasilnya menunjukkan bahwa seluruh item soal dalam angket tersebut reliabil. Item soal dalam angket dinyatakan reliabil karena nilai koefisien reliabilitas $0,831>0,6$ pada taraf signifikansi 0,05 Oleh karena itu item soal dalam angket dapat digunakan untuk mengambil data dalam penelitian.

b. Uji Reliabilitas Minat

Pengujian reliabilitas untuk angket minat dilakukan atas dasar rekapitulasi jawaban responden untuk angket minat dengan menggunakan program SPSS for windows 16.0. 
Hasilnya menunjukkan bahwa seluruh item soal dalam angket tersebut reliabil. Item soal dalam angket dinyatakan reliabil karena nilai koefisien reliabilitas 0,784 >0,6 pada taraf signifikansi 0,05 Oleh karena itu item soal dalam angket dapat digunakan untuk mengambil data dalam penelitian.

c. Uji Reliabilitas Sikap

Pengujian reliabilitas untuk angket minat dilakukan atas dasar rekapitulasi jawaban responden untuk angket sikap dengan menggunakan program SPSS for windows 16.0.

Hasilnya menunjukkan bahwa seluruh item soal dalam angket tersebut reliabil. Item soal dalam angket dinyatakan reliabil karena nilai koefisien reliabilitas 0,826 >0,6 pada taraf signifikansi 0,05 Oleh karena itu item sol dalam angket dapat digunakan untuk mengambil data dalam penelitian .

\section{Pengujian Hipotesis}

Pengujian hipotesis dalam penelitian adalah pengujian untuk mencari hubungan sekaligus pengaruh motivasi dan minat terhadap sikap untuk berwirausaha pada mahasiswa Program Studi Ekonomi IKIP PGRI Madiun.

Untuk uji hipotesis tidak digunakan perhitungan secara manual, akan tetapi digunakan alat bantu program SPSS for windows 16.0 yang diperoleh hasil sebagai berikut:

\section{Uji Korelasi}

Uji korelasi dilakukan untuk mencari keeratan hubungan antara motivasi dan minat terhadap sikap berwirausaha.

a. Hipotesis

Hipotesis yang dikemukakan dalam uji korelasi adalah sebagai berikut:

1) $\mathrm{H}_{0}$ ditolak bila nilai $\operatorname{Sig}_{\text {hit }} \leq \operatorname{Sig}_{\text {prob }}$ atau $r_{\text {hitung }} \geq r_{\text {tabel }}$ berarti ada hubungan motivasi dan minat terhadap sikap berwirausaha.

2) $\mathrm{H}_{0}$ diterima bila nilai $\mathrm{Sig}_{\text {hit }}>\mathrm{Sig}_{\text {prob }}$ atau $\mathrm{r}_{\text {hitung }}<\mathrm{r}_{\text {tabel }}$ berarti tidak ada hubungan motivasi dan minat terhadap sikap berwirausaha

b. Hasil Analisis Data.

Dari perhitungan SPSS dapat diketahui bahwa nilai $r_{\text {hit }}$ adalah 0,973 sedangkan nilai $\mathrm{r}_{\text {tab }}$ dengan taraf signifikansi $5 \%$ dengan $\mathrm{N}$ sebanyak 30 sebesar 0,361 . Hal ini berarti bahwa $r_{\text {hit }} \geq r_{\text {tabel }}(0,973 \geq 0,361)$. Keadaan ini dapat dikatakan bahwa $\mathrm{H}_{0}$ ditolak dan Ha diterima artinya terdapat hubungan motivasi dan minat terhadap sikap berwirausaha.

Dilain pihak apabila dilihat dari determinasi atau sumbangan motivasi dan minat terhadap sikap berwirausaha dapat dilihat dari besarnya nilai $R^{2}$. atau $R$ sequare sebesar 0,947 keadaan ini dapat dikatakan bahwa sumbangan motivasi dan minat terhadap sikap berwirausaha sebesar $97,70 \%$, sedangkan sisanya 2,30\% dipengaruhi oleh faktor lain.

\section{Uji F/Uji Fisher/Uji Keseluruhan}

Uji Fisher dilakukan untuk mengetahui pengaruh secara keseluruhan variabel yang ada pada motivasi dan minat terhadap sikap berwirausaha.

a. Hipotesis

Dalam uji Fisher Hipotesis yang digunakan adalah sebagai berikut:

1) $\mathrm{H}_{0}$ ditolak bila nilai $\mathrm{F}_{\text {hit }} \geq \mathrm{F}_{\text {tabl }}$ atau $\operatorname{Sig}_{\text {hit }} \leq \operatorname{Sig}_{\text {prob }}$ berarti ada pengaruh secara keseluruhan motivasi dan minat terhadap sikap berwirausaha.

2) $\mathrm{H}_{0}$ diterima bila nilai $\mathrm{F}_{\text {hit }}<\mathrm{F}_{\text {tab }}$ atau $\mathrm{Sig}_{\text {hit }}>\mathrm{Sig}_{\text {prob }}$ berarti tidak ada pengaruh secara keseluruhan motivasi dan minat terhadap sikap berwirausaha.

b. Hasil Analisis Data 
Dari hasil uji Anova dapat diketahui bahwa nilai $F_{\text {hit }}$ sebesar 240,667 sedangkan nilaiF $_{\text {tabel }}$ pada taraf signifikansi $5 \%$ dengan $\mathrm{Df} 2$ dan residu 27 sebesar 5,49. Dilain pihak nilai Sighit sebesar 0,000 dan nilai $\mathrm{Sig}_{\text {prob }}$ besarnya 0,05 . Hal ini berarti bahwa $F_{\text {hitung }} \geq F_{\text {tabel }}(240,667 \geq 5,49)$ atau $\mathrm{Sig}_{\text {hit }} \leq \operatorname{Sig}_{\text {prob }}(0,000 \leq 0,05)$. Dengan demikian $\mathrm{H}_{0}$ ditolak, artinya ada pengaruh secara keseluruhan motivasi dan minat terhadap sikap berwirausaha.

Selain digunakan untuk mencari pengaruh uji Fisher atau Anova ini digunakan untuk uji linearitas. Karena nilai $F_{\text {hitung }}$ sebesar $240,667 \geq F_{\text {tabel }}$ sebesar 5,49, berarti terdapat hubungan yang linier antar dua variabel yakni motivasi dan minat terhadap sikap berwirausaha.

\section{Uji t/Uji Beda/Uji Koefisien Regresi}

Uji t dilakukan untuk mencari beda pengaruh antara setiap variabel yang ada dalam motivasi dan minat terhadap sikap berwirausaha.

a. Hipotesis

Hipotesis yang digunakan dalam uji $t$ adalah sebagai berikut:

1) $H_{0}$ ditolak bila nilai $t_{\text {hit }} \geq t_{\text {tab }}$ atau $\operatorname{Sig}_{\text {hit }} \leq \operatorname{Sig}_{\text {prob }}$ berarti ada beda pengaruh motivasi dan minat terhadap sikap berwirausaha.

2) $\mathrm{H}_{0}$ diterima bila nilai $\mathrm{t}_{\text {hit }}<t_{\text {tab }}$ atau $\mathrm{Sig}_{\text {hit }}>\mathrm{Sig}_{\text {prob }}$ berarti tidak ada beda pengaruh motivasi dan minat terhadap sikap berwirausaha.

b. Hasil Analisis Data

Dari perhitungan SPSS diperoleh hasil sebagai berikut:

1). Persamaan Garis Regresi dinyatakan dengan:

$\mathrm{Y}=2.514+0,745 \mathrm{X}_{1}-0,086 \mathrm{X}_{2}$.

Dari persamaan tersebut dapat dinyatakan :

a) Apabila motivasi dinaikan dengan 1\%, akan terjadi kenaikan sikap berwirausaha sebesar $0,745 \%$, apabila factor lainnya dianggap konstan.

b) Apabila minat dinaikan dengan $1 \%$, akan terjadi penurunan sikap berwirausaha sebesar $0,086 \%$, apabila factor lainnya dianggap konstan.

2) Dalam Uji t

Dalam uji t dari perhitungan diperoleh hasil sebagai berikut:

a) Variabel motivasi diperoleh nilai $t_{h i t}$ adalah 20,670 sedangkan nilait $_{\text {tabel }}$ pada taraf signifikansi $5 \%$ dan pada $\mathrm{DK}=\mathrm{N}-\mathrm{K}=27$ sebesar 2,052, hal ini berarti $t_{\text {hitu }} \geq t_{\text {tab }}(20,670 \geq 2,052)$ artinya ada beda pengaruh variable motivasi terhadap sikap berwirausaha

b) Variabel minat diperoleh nilai $t_{\text {hit }}$ adalah $-2,050$ sedangkan nilai $\mathrm{t}_{\text {tabel }}$ pada taraf signifikansi $5 \%$ dan $\mathrm{DK}=\mathrm{N}-\mathrm{K}=27$ sebesar 2,052, hal ini berarti $\mathrm{t}_{\text {hitu }} \leq \mathrm{t}_{\mathrm{tab}}(-2,05 \leq 2,052)$ artinya tidak ada ada beda pengaruh minat terhadap sikap berwirausaha.

\section{Simpulan Hasil Analisis}

Dari hasil analisis data yang telah dilakukan dapat diambil simpulan sebagai berikut:

a. Simpulan Uji Korelasi

Dalam uji korelasi diperoleh nilai $r_{\text {hit }}$ adalah 0,973 sedangkan nilai $r_{\text {tab }}$ dengan taraf signifikansi $5 \%$ dengan $\mathrm{N}$ sebanyak 30 sebesar 0,361 . Hal ini berarti bahwa $r_{\text {hit }} \geq r_{\text {tabel }}(0,973 \geq 0,361)$. Keadaan ini dapat dikatakan bahwa $\mathrm{H}_{0}$ ditolak dan Ha diterima artinya terdapat hubungan motivasi dan minat terhadap sikap berwirausaha. 
Dilain pihak apabila dilihat dari determinasi atau sumbangan motivasi dan minat terhadap sikap berwirausaha dapat dilihat dari besarnya nilai $\mathrm{R}^{2}$. atau $\mathrm{R}$ sequare sebesar 0,947 keadaan ini dapat dikatakan bahwa sumbangan motivasi dan minat terhadap sikap berwirausaha sebesar $97,70 \%$, sedangkan sisanya 2,30\% dipengaruhi oleh faktor lain.

Sesuai dengan hipotesis yang telah dikemukakan dapat disimpulkan bahwa terdapat hubungan antara motivasi dan minat terhadap sikap berwirausaha.

b. Simpulan Uji Fisher

Dari hasil analisis data yang telah dilakukan untuk uji Fisher diperoleh hasil bahwa nilai $F_{\text {hit }}$ sebesar 240,667 sedangkan nilaiF $F_{\text {tabel }}$ pada taraf signifikansi 5 $\%$ dengan Df 2 dan residu 27 sebesar 5,49. Dilain pihak nilai $\mathrm{Sig}_{\text {hit }}$ sebesar 0,000 dan nilai $\mathrm{Sig}_{\text {prob }}$ besarnya 0,05 . Hal ini berarti bahwa $F_{\text {hitung }} \geq F_{\text {tabel }}$ $(240,667 \geq 5,49)$ atau $\operatorname{Sig}_{\text {hit }} \leq \operatorname{Sig}_{\text {prob }}(0,000 \leq 0,05)$. Dengan demikian $H_{0}$ ditolak, artinya ada pengaruh secara keseluruhan motivasi dan minat terhadap sikap berwirausaha.

c. Simpulan Uji t

Dari hasil analisis yang digunakan dalam uji t diperoleh :

1) Persamaan regresi sebagai berikut: $Y=2.514+0,745 X_{1}-0,086 X_{2}$ Dapat disimpulkan dari persamaan tersebut adalah

a) Apabila motivasi dinaikan dengan $1 \%$, akan terjadi kenaikan sikap berwirausaha sebesar $0,745 \%$, apabila factor lainnya dianggap konstan.

b) Apabila minat dinaikan dengan 1\%, akan terjadi penurunan sikap berwirausaha sebesar $0,086 \%$, apabila factor lainnya dianggap konstan.

2). Dalam Uji t

Dalam uji t. diperoleh hasil sebagai berikut:

a) Variabel motivasi diperoleh nilai $t_{\text {hit }}$ adalah 20,670 sedangkan nilai $\mathrm{t}_{\text {tabel }}$ pada taraf signifikansi $5 \%$ dan pada $\mathrm{DK}=\mathrm{N}-\mathrm{K}=27$ sebesar 2,052 , hal ini berarti $t_{\text {hitu }} \geq t_{\text {tab }}(20,670 \geq 2,052)$ artinya ada beda pengaruh variable motivasi terhadap sikap berwirausaha.

b) Variabel minat diperoleh nilai $t_{\text {hit }}$ adalah $-2,050$ sedangkan nilai $t_{\text {tabel }}$ pada taraf signifikansi $5 \%$ dan $\mathrm{DK}=\mathrm{N}-\mathrm{K}=27$ sebesar 2,052, hal ini berarti $\mathrm{t}_{\text {hitu }} \leq \mathrm{t}_{\mathrm{tab}}(-2,050 \leq 2,052)$ artinya tidak ada ada beda pengaruh minat terhadap sikap berwirausaha.

\section{Simpulan - Saran}

Dari penelitian yang berjudul “ Analisis tentang pengaruh motivasi dan minat terhadap sikap mahasiswa untuk berwirausaha pada mahasiswa Program Studi Pendidikan Ekonomi dapat disimpulkan sebagai berikut :

1. Berdasarkan rekapitulasi jawaban angket variabel motivasi berwirausaha setelah dianalisis dengan statistik diskriptif dengan SPSS for Windows v 16.0 diperoleh hasil bahwa variabel motivasi dengan jumlah data $(\mathrm{N})$ sebanyak 30 orang memiliki deskripsi data sebagai berikut: (a) Nilai total skor sebesar 378; (b) Nilai mean sebesar 24,60; (c) Nilai median sebesar 26,00; (d) Nilai modus sebesar 26; (e) Standar deviasi sebesar 3,838; (f) Nilai minimum sebesar 15; (g) Nilai maksimum sebesar 32 .

2. Variabel minat dalam penelitian berdasarkan jawaban angket yang diberikan kepada 30 orang responden Setelah dianalisis dengan statistik diskriptif dengan SPSS for Windows v 16.0 diperoleh hasil bahwa :

variabel minat berwirausaha dengan jumlah data $(\mathrm{N})$ sebanyak 30 orang memiliki deskripsi data sebagai berikut: (a) Nilai total skor sebesar 728; (b) Nilai mean sebesar 24,23; (c) Nilai median sebesar 25,00; (d) Nilai modus sebesar 26; (e) 
Standar deviasi sebesar 3,298; (f) Nilai minimum sebesar 15; dan (g) Nilai maksimum sebesar 32 .

3. Variabel sikap berwirausaha dalam penelitian ini diperoleh dari kuisioner yang dimiliki oleh 30 orang responden setelah dianalisis dengan statistik diskriptif dengan SPSS for Windows v 16.00 diperoleh hasil yaitu bahwa variabel sikap berwirausaha mahasiswa dengan jumlah data $(\mathrm{N})$ sebanyak 30 orang memiliki deskripsi data sebagai berikut: (a) Nilai total sikap sebesar 563; (b) Nilai mean sebesar 18,77 (c) Nilai median sebesar 20,00; (d) Nilai modus sebesar 20; (e) Standar deviasi sebesar 3,025; (f) Nilai minimum sebesar 10; (g) Nilai maksimum sebesar 24.

4. Terdapat hubungan antara motivasi dan minat terhadap sikap berwirausaha pada mahasiswa Program Studi Pendidikan Ekonomi IKIP PGRI Madiun. Hali ini terbukti dari perhitungan SPSS bahwa nilai $r_{\text {hit }}$ adalah 0,973 sedangkan nilai $r_{\text {tab }}$ dengan taraf signifikansi $5 \%$ dengan $\mathrm{N}$ sebanyak 30 sebesar 0,361 . Hal ini berarti bahwa $r_{\text {hit }} \geq r_{\text {tabel }}(0,973 \geq 0,361)$.

Dilain pihak apabila dilihat dari determinasi atau sumbangan motivasi dan minat terhadap sikap berwirausaha dapat dilihat dari besarnya nilai $\mathrm{R}^{2}$. atau $\mathrm{R}$ sequare sebesar 0,947 keadaan ini dapat dikatakan bahwa sumbangan motivasi dan minat terhadap sikap berwirausaha sebesar $97,70 \%$, sedangkan sisanya 2,30\% dipengaruhi oleh faktor lain.

5. Ada pengaruh secara keseluruhan antara variabel motivasi dan minat terhadap sikap berwirausaha mahasiswa Program Studi Pendidikan Ekonomi IKIP PGRI Madiun .Ini terbukti dari hasil uji Anova bahwa nilai $F_{\text {hit }}$ sebesar 240,667 sedangkan nilai $F_{\text {tabel }}$ pada taraf signifikansi $5 \%$ dengan $\mathrm{Df} 2$ dan residu 27 sebesar 5,49. Dilain pihak nilai $\mathrm{Sig}_{\text {hit }}$ sebesar 0,000 dan nilai $\mathrm{Sig}_{\text {prob }}$ besarnya 0,05. Hal ini berarti bahwa $F_{\text {hitung }} \geq F_{\text {tabel }}(240,667 \geq 5,49)$ atau $\operatorname{Sig}_{\text {hit }} \leq \operatorname{Sig}_{\text {prob }}(0,000 \leq$ $0,05)$.

Selain digunakan untuk mencari pengaruh uji Fisher atau Anova ini digunakan untuk uji linearitas. Karena nilai $F_{\text {hitung }}$ sebesar 240,667 $\geq F_{\text {tabel }}$ sebesar 5,49, berarti terdapat hubungan yang linier antar dua variabel yakni motivasi dan minat terhadap sikap berwirausaha.

6. Dari persamaan regresi $\mathrm{Y}=2.514+0,745 \mathrm{X}_{1}-0,086 \mathrm{X}_{2}$ berarti apabila motivasi dinaikan dengan $1 \%$, akan terjadi kenaikan sikap berwirausaha sebesar $0,745 \%$, apabila faktor lainnya dianggap konstan.

Apabila minat dinaikan dengan 1\%, akan terjadi penurunan sikap berwirausaha sebesar $0,086 \%$, apabila faktor lainnya dianggap konstan.

Dari Variabel motivasi diperoleh nilai $t_{h i t}$ adalah 20,670 sedangkan nilai $t_{\text {tabel }}$ pada taraf signifikansi $5 \%$ dan pada $\mathrm{DK}=\mathrm{N}-\mathrm{K}=27$ sebesar 2,052, hal ini berarti $\mathrm{t}_{\text {hitu }} \geq$ $\mathrm{t}_{\text {tab }}(20,670 \geq 2,052)$ artinya ada beda pengaruh variabel motivasi terhadap sikap berwirausaha.

Dari Variabel minat diperoleh nilai $t_{\text {hit }}$ adalah $-2,050$ sedangkan nilai $t_{\text {tabel }}$ pada taraf signifikansi $5 \%$ dan $\mathrm{DK}=\mathrm{N}-\mathrm{K}=27$ sebesar 2,052 , hal ini berarti $\mathrm{t}_{\text {hitu }} \leq$ $\mathrm{t}_{\text {tab }}(-2,050 \leq 2,052)$ artinya tidak ada beda pengaruh minat terhadap sikap berwirausaha.

\section{Saran - saran}

1. Bagi dosen pengajar mata kuliah Kewirausahaan.

Dalam memberikan kuliah hendaknya selalu memberikan motivasi sehingga dapat menimbulkan minat dan akhirnya terdapat sikap bahwa kewirausahaan merupakan alternatif pilihan bagi mahasiswa selain menjadi guru.

2. Bagi para mahasiswa. 
Dalam mengikuti perkuliahan kewirausahaan hendaknya menjadi bahan pemikiran dan arahan yang berguna untuk menciptakan lapangan pekerjaan sendiri yaitu berwirausaha.

3. Bagi pengelola pendidikan.

Dalam upaya untuk menumbuh kembangkan kewirausahaan hendaknya memberikan peluang atau kesempatan berupa latihan ataupun ketrampilan serta praktek yang merupakan persiapan menuju kewirausahaan yang sesungguhnya.

\section{DAFTAR KEPUSTAKAAN}

Abin Syamsudin Makmur,2009, Psikologi Pendidikan, Bandung:PT.Remaja Rosdakarya

Buchari Alma,2005.Kewirausahaan, Bandung: Alfabeta

Buchari,1991.Psikologi Pendidikan.Jakarta:PT Rineka Cipta

Djarwanto, Ps. dan Pangestu Subagyo. 2000. Statistik Induktif. Yogyakarta: BPFE

Ghozali, Imam.2005. Analisis Multivariat dengan Program SPSS.Semarang:Badan Penerbit Universitas Diponegoro

Husaini Usman;Purnomo Setiadi Akbar,2006,Pengantar Statistika,edisi Kedua,Jakarta:PT.Bumi Aksara

Nana Sudjana,1989.Penilaian Hasil Proses Belajar Mengajar .Bandung: PT Remaja Rosdakarya

Nana Syaodih Sukmadinata,2011.Landasan Psikologi Proses Pendidikan Bandung:PT Remaja Rosdakarya

Sugiyono. 2010. Metode Penelitian Pendekatan Kuantitatif, Kualitatif, $R$ \& D. Bandung: Alfabeta.

Yeanne Ellis Ormrod, 2008, Psikologi Prndidikan membantu siswa tumbuh dan Berkembang, Jilid 2, Jakarta: Erlangga

Yudrik Yahja,2011, Psikologi Perkembangan,Jakarta:Kencana Prenada Media Group 
